

\section{Society and Reformation in the Ismaili Community of Bamiyan, Afghanistan}

HAFIZULLAH EMADI

Scholar

Los Angeles

USA

\section{Introduction}

Radicalization of individuals and groups is a response to their perceived collective grievances. This is more evident in the developing world where the majority of citizens remain poor, marginalized and deprived of the basic necessities of life. Although different groups have different agendas, their struggle is either norm or value oriented. The norm-oriented movements werc concerned with producing limited change in the existing order while the value-oriented movements were concerned with large scale change in the system. Social movements often take violent forms in the developing world where activists confront the ruling elites who rely on external powers for their sustenance, demanding an end to exclusive political, economic and social policies and practices. Different disciplines examine the issue of radicalization in different ways. The psychological paradigm stresses personality traits when determining behavior. Included in this analysis is the rational-calculation perspective where activists assess their chances for victory and defeat and decides accordingly. The social-psychological paradigm that stresses the relationship between social structural and psychological perspectives shows how social relations and interactions influence psychological dispositions of individuals and participation in social movements. The social-structural perspective postulates on societal determinants, influencing individuals and groups participation in social movements. Material conditions not only affect patterns of socio-economic activities but also influence the way in which individuals and groups think and articulate their expectations and desires.

This article examines social movements for change and reform in the Ismaili community of the Shibar district of Bamiyan in Afghanistan. The social-structural theory guides the analysis throughout the article as it provides a broader understanding of societal factors that lead to radicalization of individuals and groups and their motivation for change, and describes the complex interplay between internal and external factors leading to social movements. 
Alghanistan's history is replete with stories focusing on the struggle for socio-political change, where individuals and groups played prominent roles. The country's cultural landscape is made up of diverse ethno-linguistic communitics. Tribalism, regionalism and sectarian confliets coupled with foreign interference impacted national unity and the country's socio-economic development. Dominant ethno-sectarian groups inside and outside the state apparatuses conspired to marginalize minority communitics in the social, cconomic and political arena, pilting one ethnic group against another to perpetuate their instability and further their own self-interests.

A plethora of research has been produced with regard to the study of political dynamics of tribal communities and the resulting social movements for change in Afghanistan, but the Hazara Ismaili community remained a neglected topic of study by scholars. Ismailis are part of the cultural landscape of Afghanistan. The ruling elass had long suppressed them politically as a strategie delensive move, depriving them of their fundamental rights and subjecting them to discrimination. Ismailis endured centuries of suffering and exploitation by despotic rulers inside and outside the government and mistreatment at the hands of their own craven religious and tribal leaders.

This article intends to remedy this lack of research with the Ismaili community of Shibar as a subject of study. It examines politics of marginalization and discrimination by the politically dominant elass and repressive measures by Ismaili tribal leaders that hindered progress toivard building a modern civil society. It also explores the role of Ismailis during and alter the Soviet occupation of the country and eflorts toward rehabilitation and modernization of the community in the post-Taliban period. A discussion of these issues aims to provide an understanding of factors that facilitated social movements attempting to modernize the rigid social, political and cultural institutions that inhibited people from participation in the community's decision-making process.

\section{The Ismailis: Society and Politics}

Ismailis are an offshoot of the Shias and Karim Aga Khan IV is the forty ninth and present Imam, religious leader of the community worldwide. Ismailis reside in various villages in Shibar. They believe that their ancestors lived in areas of Tirin and Deh Rawod in the southern part of Orazgan province and were driven out of the region due to rising hostilities tovvard their faith. They belong to the Khatai Hazara tribe and maintain they are descendents of Khatai's two sons, Darghan who settled in Shibar, and Qarloq who settled in Shaikh Ali, Parwan province. Different tribal communitics in Shibar trace their genealogy to one of Darghan's many sons: Noka (residents of Sar-e-Kotal), Shaikha (residents of several villages of Shibar such as Daki and others), Khida (residents of Iraq, Shunbul and Bululah) Haram Shah (Hazaras of central Bamiyan), Gudi (residents of Shunbul and Jola) and Shikay, Shaga or Shakh (residents of Birgilich).'

Shibar's population was estimated to be 19,002 in 2003 and its ethnic composition includes 47 percent Sunni Tajiks, 35 percent Shia Hazaras, 17 percent Ismaili Hazaras and I percent Shia Sayyeds. Ethnic composition of the five major valleys in Shibar include 98 percent Tajiks and 2 percent Hazaras in Ghandak and Jalmish; 70 percent Shia and 30 percent Ismaili Hazaras in Shunbul and Shibar; and 95 percent Shia and 5 percent Ismaili Hazaras in Kalu.

The primary social classes are landowners and the peasantry. Landowners play a prominent role in the social and political affairs of the community and they are known by the titles of Khan. Pir, religious leaders also known by the title of Mukhi (a Gujrati word refers to those who preside over religious services) who came from landowning families. were situated at the top of the social hierarchy. They claim to be Savyed descendents of Ali, the first Shia Imam and the fourth

1. Discussions ivith elderly ismuilis of Shibar, Kabul, 2005 ,

2. UNHCR, Sub-oflice. Central Region, District Profile, Geo-code 2801, September 18, 2002 , 
Muslim Caliph (656-661), however most of their claims are difficult to prove with ecrtainty. They nonetheless wielded considerable social, economic, political and religious influence and ruled their community of followers as they pleased. One such a figure was Abdul Hadi of Kayan, Baghlan who scized leadership of the Ismailis including Shibar in the early $19^{\text {th }}$ eentury; alter his death his descendents continued to lead the eommunity until 2002. The leadership further consolidated their position by establishing social networks and appointing Irusted men as Khalifa or resident representative in lsmaili-settled regions to protect and defend their interests.

The Mir and Arbab are another prominent social strata. They generally belong to wealthy families and are elected by members of a village or a cluster of villages to represent them in government agencies, performing services such as assisting the government in the collection of taxes, finding recruits to the army, and mobilizing people for bigari. corvee labor such as road repair. They also represented the plaintiffs and defendants who took outstanding issues for resolution to the government's court and mediated between conflicting parties, charging them fees to bribe government officials to resolve cases pending against their clients, while keeping the bulk of the money for themselves.

Mullahs, clerics are a distinct social group as they impart basic religious education to children, interpret religious scriptures and supervise cultural and religious rituals and ceremonies in their villages. Most Mullahs are farmers and their level of education extends to mastering a few classic religious texts related to the Ismaili faith and remaining loyal to the Pir and in the following his instructions.

The majority of people in this region are pastoral farmers. Average landholding size ranges from 2 to 5 Jeribs of irrigated and non-irrigated land ( 1 Jerib $=$ one filth of a hectare) and available agricultural equipment in 1990 included 64 mills and 1.230 plows. Water for irrigation is scarce and major sources of water in 1990 included 18 wells, 185 springs and 15 kariz, underground water channels. Local industries include weaving woolen curpets and rugs, namad, a fleece-like mattress made of wool, handloom woven cloth, leather products, wood carvings, straw baskets. and houschold utensils. Small industries did not develop fully due to lack of credit and modern equipment. Poor farmers worked as masons, artisans and ran small stores selling produce and sundries, clothes, fabrics, etc. when they are free from agricultural work and in the winter season. They labored from dawn to dusk to feed their families and to sustain the comfortable life of the oppressing rural elite. In 1990 there vvere 5 bazaars and 20 Sarai, inns in Shibar, the bazaar along the Shikari Valley had about 30 shops and that in Ghandak about 35-40 shops. Table 1 shows the number of people engaged in non-agricultural activities in Shibar in 1990.

\section{State and Politics of Repression}

Hazaras led a semi-autonomous life until King Abd al-Rahman (1880-1901) decided to subjugate peripheral regions to his rule. He waged war on Hazaras, conquered them and established his rule over Hazarajat in 1893. The svar not only claimed the lives of many people but also led to enslavement of Hazaras and caused scores of others to seek refuge in Pakistan, Iran and Russia. Hazaras were sold as slaves to affluent families and whenever Abd al-Rahman met his subjects he reminded them to be appreciative of his leadership for enslaving the Hazaras, otherwise they "would have had to work like donkeys if it svere not that the slaving donkeys of Hazaras do all the work for them."' Although Abd al-Rahman viewed Hazaras as yaghi, outlaws who were eager to join foreign forces against him, his characterization of the Hazaras is in sharp contradiction to that of his British personal physician who wrote that "[Hazaras| compared with the Afghans [Pashtuns],

3. Sultan Mahomed Khan (ed.) with introduction by M.E. Yapp. The Life of Alodur Rol/man: Amir of A/ghanistan. Vol. I (London: Jolın Murray, 1980). Reprinted (Karachi: Oxford University Press, 1990), p. 276. 
Table I

Availability of Skilled Shia and Ismaili Laborers in Shibar, 1990

\begin{tabular}{|l|c|}
\hline \multicolumn{1}{|c|}{ Type of Laborer } & Number of Laborer \\
\hline Blacksmith & 86 \\
Carpenter & 208 \\
Carpet Weaver & 2.230 \\
Construction Worker & 220 \\
Coppersmith & 93 \\
Driver & 425 \\
Kariz-digger & 63 \\
Mechanic & 84 \\
Midwile & 224 \\
Tailor & 155 \\
Trained teacher & 90 \\
Unskilled Laborer & 713 \\
Untrained teacher & 198 \\
\hline
\end{tabular}

Source: A/ghunistan: Bamiyan Ponince, A Socie-Econtemic Profile (Kabul: UNIDATA. A project of UNDP/OPS \& UNOCA. n.d.).p. 7. Unpublished repart.

a hard working peacelul people, unless they were roused by cruelty and oppression; then. indeed, they lought with dogged persistence."-

Abd al-Rahman forced Hazaras to renounce their faith and praying in Sunni mosques. Despite his Islamic zeal Abd al-Rahman himself did not abide by Islamic teachings nor said the five-time daily prayers. His personal physician wrote that "His Highness the Amir does not pray, at least as far as I know. I have never seen him do so." ${ }^{\text {"5 }}$ Abdul Rahman distributed the lands of Hazaras who fled Hazarajat to the Pashtuns and granted permission to Kochis, Pashtun nomads to graze their animals on the pasture lands in Hazarajat in exchange for their role in helping him defeat the Hazaras armed resistance to his rulc. He partitioned Hazarajat under the administrative control of provinces of Kabul, Bamiyan and Qandahar - an attempt intended to eliminate the possibility of Hazara unity in the future.

When Abd al-Rahman launched an offensive to dislodge his cousin Mohammad Ishaq, administrator of the Turkistan region in the north, his cousin formed an alliance with tribal leaders, fought Abd al-Rahman but was defeated. Ismailis in the Turkman Valley, Shaikh Ali of Parwan province and Shibar of Bamiyan province who endured miseries and no longer could afford paying heavy laxes seized the opportunity and rebelled against the government and arrested the state appointed local administrator. After Abd al-Rahman dispatched an army to suppress the rebellion non-Ismaili residents of the regions supported the government and they defeated the Ismailis; they looted Ismaili houses and seized their belongings, their animals and their women and girls. The state internally exiled a number of families to remote areas such as Badakhshan, Herat, Logar, Girishk and Balkh regions while others endured harsh labor in government factories in Kabul. Although later Abd al-Rahman ordered his marauding soldiers to return properties seized from the Ismailis, people did not take them back with the hope to further please the ruling dictator.

4. John Alfred Gray. At the Court of the Amir: A Narrutive (London: Richard Bentley and Son, I895), p. 206.

5. Ibid, p. 95 . 
The Ismaili Ieader Sayed Jafar and a number of lsmailis were forced to leave for the Kulyab region of Central Asia and these who stayed home were forced to maintain Tayiyya (dissimulation of one's faith in a hostile environment) in order to avoid persecution. Abd al-Rahman's repressive policies provoked lsmaili individuals in Shibar to rebel against him in the late 1880s. Ali Shir and a number of his men attacked a caravan carrying the king's family members to Kabul via Bamiyan in the vicinity of the Hajigak Pass, looted the treasury and ravaged the women, including a woman who was reportedly a wife. handmaiden or concubine of King Shir Ali, uncle of Abd al-Rahman who died in Mazar, Balkh on February 21, 1879. It is reported that when Abd al-Raman approached this woman to have relations with her she told him that her man was still alive. Abd al-Rahman reminded her that King Shir Ali is dead; she told him that Ali Shir of Shibar who raped her is still alive. The news infuriated Abd al-Rahman: he dispatched a force to Shibar that arrested scores of people including Ali Shir and transferred them to Kabul. Abd al-Rahman executed Ali Shir and imprisoned his associates. Inmates who were freed later described the suffering and torture they endured in prison and recounted Ali Shir's response to Abd al-Rahman when the ruling dictator interrogated him about the molestation of the woman. Furious, Abd al-Rahman shouted to Ali Shir asking whether he was aware that Abd al-Rahman is alive. Ali Shir knew that his fate was sealed and defiantly responded that when "his Abd al-Rahman" became erect [referring to his penis] it was oblivious to the "other Abd al-Rahman" [the ruler of Kabull.," Abd al-Rahman imposed a fine of one lak or 100,000 Rupees as a collective punishment on Shibar's residents in retaliation for Ali Shir's actions and insults - an amount which poor families could not afford to pay. People do not remember the date in which the incident occurred but call it the year of lak. Canfield described the incident and collection of taxes in these words:

\footnotetext{
"Tivo or three hundred Hazara men at some time during Abd al-Rahman's reign raided his caravan in the vicinity of Hiajigatk Pass. They took everything of value but allowed the royal lady and her party to go without further insult. The Amir, however, appears to have been easily able to gain his retribution on these outlaws. for he jailed some of the Hazara leaders, placing a fine of 100.000 Afghanis. Afs [Rupees] on each of them payable before their release. while other persons sought by the government fied to the north and stiyed atvay until Habibullah, his son. upon taking the rulership, commuted their sentences, Altogether about ten laks (i.e, $1,000,000)$ of Afs, were actually paid in fines by those rich enough to obtain the release of those prisoners."
}

Tax collecting officers extorted additional money, causing further suffering to the people. When Abd al-Rahman was on his way to the northern regions via Shibar, residents of the region prepared a resting area for him in Dahan-e-Khukkushta Valley. When Abd al-Rahman was about to leave Shibar, people made a humble request for a less burdensome tax levy as they could not pay any more. It is suggested that Abd al-Rahman told them: lak-e-kliudra didid magar laki mara nadidid Iyou noticed your own lak, referring to the sexual molestation of the woman of the ruling family and were ignorant of my own lakl, and did not rescind the tax. ${ }^{*}$ After Abd al-Rahman's death his son Habibullah revised his father's policies and declared a general amnesty in 1904. Exiled Ismaili

6. Whenever the author's late father Mr. Afghan, invited his mother Ziba, her brothers Ghayb Ali and Barg Ali to bis house for dinner. Ziba often told this story. She had learned it from her own grandparents and other residents of Shibar twho have passed the story down through the generations so it will not be forgoten by the younger residents of Shibar.

7. Roben L. Canfield, Factien und Comversion in a Plural Suciety: Religions Aliguneuts in the Hindu Kush (Ann Arbor: The University of Michigan, 1973). pp. 99-100. Notes: The local currency in Afghanistan was called Rupce and one Kabuli Rupee was equal to one Indian Rupee in 1880. In 1890-1914 the value of one Kabuli Rupee ivas equal to eight pence. Kabuli Rupees were struck in silver and a few were in gold. During the reign of Abd al-Rahman one Rupee was valued quite highly. In 1924 the exchange rate was $\$ 1.0=A f s .4 .73$ and on January 20.2101 , the currency depreciated to the extent that $\$ 1,0=\mathrm{Afs}, 54,000$ and on May 31.2005, the rate tvas $\$ 100=49.80 \mathrm{Afs}$.

8. The word lak in the Hazarag dialect of the Persian Language also refers to erection of a man's penis. Discussions with elderly Hizara Ismailis of Shibar. Bamiyan. 1976. 
Pir Sayed Timoor availed this opportunity and returned home. Although the situation of Ismailis did not improve during Habibullah`s rule, Ismailis remained supportive of his government.

\section{Status of Ismailis in the Post-Independence Period}

After Habibullah's assassination in 1919) his son Amanullah aseended to the throne. He freed Hazaras from slavery and considered them on equal footing with other citizens. Hazaras supported Amanullah and even fought to restore him to power when Habibullah, known by a derogatory name, bacher-e-sacqaw, water-carricr's son (a reference to his father's occupation) from Kalakan, drove him out of Kabul and seized power in January 1929." When people in Shibar defied Habibullah's rule he dispatched a tribal army composed of the Tajiks to Shibar to bring the region under his control. Anti-Habibullah resistance in Shibar has been described in these words:

"In the time of Bacha-e Salyen the hrother of the deposed King Amanullath was traveling in Hazarajat to gather support for him. I had been sent along with several others to join the followers of the former King. We earried money in the form of silver coins sewed in our belts. which made them extremely heavy because at that time $1,(0) 0$ Afghanis, pure silver. weighed about 20 pounds. Each of us was carrying 2.500 Afghanis, that is about 50 pounds apiece, but on the way some Tijiks, whom we at lirst took to be friendly, robbed us of our horses, and firearms. So the result was that we lost everything and were no help to the King.. After Amanullah lost the battle with Satgen in Kabul, we heard that 600 men from Amanullah's army were coming to Shibar to join our resistance against Saqaw. Only 300 of these reached Shibar, the others having been killed or frightened atvay. These stond with the people of Shibar for nine months of trouble."

When the civil war ended in October 1929, the Ismailis supported the government of King Mohammid Nadir because their religious leader. Sayed Nader Kayani (1897-1971) had cultivated friendly relations with him when he was defense minister in Amanullah's cabinet. Despite this relationship the state did not devise policies to improve the lot of Ismailis. Political and religious discrimination and repression by the Sunni majority persuaded the Shias and Ismailis to coexist peacefully, helping each other in times of need and some families even arranged marriages between their children despite doctrinal differences. The practice came to an end when external pressures eased and dogmatic cleries and conservative leaders of both communities refused to endorse familial ties among members of the two communities.

Hazaras continued to endure transgressions by the Kochis who not only grazed their llocks on their pasture lands but also exploited the people by engaging in predatory business transactions that caused poor families to remain indebted and at the mercy of the Kochis.

"They [Kochis] were elever. They would lend money and get the repayment in Secrs of wheat [1 Seer $=16.3 \mathrm{lbs} /$ which increased in value every year. Then they would add interest. Even if you could pay them back the next summer, you paid several times more than you had borrowed. They would only accept payment in wheat. not cash. Those who did not have enough wheat could lose their land very easily."

Senior government officials were Sunni Pashtuns and supportive of the Kochis. In the late 1960s a Kochi murdered his companion near the Shibar Pass, reported the incident to the district governor,

9. For detailed information see, Hafizullah Emadi, "The Hazaras and their role in the process of political transformation in Afglanistan. Central Asian Survecy, 16:3 (1997).

10. Robert L. Canticld. op. cit., pp. $104-105$. Notes: Exchange rate in 1929 wals around $\$ 1.0=A f s, 6,22$.

11. Liz Adden Wily, Lamal Relanows in Bamiycan Province: Findings from a 15 Village Case Sudy (Kabul: Afghanistan Research and Evaluation Unit, 2()04),p. 33. 
implicated the Hazaras for the murder and demanded that oflicials prosecute those responsible. Government oflicials exploited the opportunity to their advantages - taking bribes and rounding up a number of suspects for questioning that lasted for months; later the case was transferred to a provincial court for arbitration which rendered a guilty verdict leading to imprisonment of an Ismaili, Mohammad, son of Toy Mohammad from Khakmushak and two Shias, Khudadad Baba Khan from Khakmushak and Amir Dad of Kuhna-Qalah for several years.

\section{Mechanisms of Control: Institutional Structures in Shibar}

A mutually reinforcing mechanism of state administration and the traditional tribal system governed the society. The district governor and security chief were appointed by the eentral government and they worked in collaboration with tribal chiefs, Mir and Arbab to ensure stability in the region. Table 2 lists prominent Ismailis of Shibar prior to the outbreak of the insurgency in 1980.

Conservative tribal chiefs and clerics did not support economic development or modern education, fearing that if people became cducated and financially self-sufficient they would no longer depend on them for guidance and leadership, however they ensured their own ehildren received a modern education. They were bent on character assassination of social activists and others who criticized societal injustices.

Economic difficultics caused poor families to migrate from Shibar to Kabul beginning in the 1950 s, where they found employment with private companies, in labor intensive industries or menial jobs. Poor families worked for affluent families as domestic servants and lived in a room in the family's compound. A few landless and poor peasant families also settled in the southern part of the country, Helmand in the 1970s when a state program distributed land to poor families.

Table 2

Influential Individuals in the Ismaili Community of Shibar

\begin{tabular}{|l|l|l|l|l|}
\hline \multicolumn{1}{|c|}{ Name } & Father Name & Rank/Title & \multicolumn{1}{|c|}{ Village } & Residence/Status \\
\hline Afghan & Bunyad & Arbab & Daki-Shibar & $1917-1977$ \\
\hline Ahmad Ali & Ali Ahmad & $\begin{array}{l}\text { Appointed } \\
\text { senator, Kabul. } \\
1988-1991\end{array}$ & Birgilich & Died, 201I \\
\hline Ali Ahmad & Ali Baig & Mir & Iraq & 1905-1980 \\
\hline Ali Ahmad Jan & - & Arbab & Quchangi & Kabul \\
\hline $\begin{array}{l}\text { Ghulam Hasan } \\
\text { (Gudamdar) }\end{array}$ & - & Mir & Shunbul & Died, 1985 \\
\hline Malik Nasir & Mir Bakhtiyari & Arbab & Kalu & Kabul \\
\hline Mir Ahmad Ali & Ali Madad & Mir & Iraq & Murdered, 1988 \\
\hline Mir Ahmad Jan & $\begin{array}{l}\text { Ghulam } \\
\text { Mohammad }\end{array}$ & Mir & Quchangi & Executed, 1978 \\
\hline Mohammad Aslam & Mullah Abdul & Khalifa & Shunbul & Died, 1970s \\
\hline Mohammad Safi & - & Cleric & Kalu & Died, 1940s \\
\hline
\end{tabular}

Shurce: Discussions widl residents of Shibar, 2006. 


\section{Modern Education and Dissemination of Radical Discourse}

The majority of residents were illiterate and dependent on semi-literate clerics for interpretation of religious scriptures and on Mir and Arbab for representing them to government agencies. They also sought help from their semi-educated children and relatives with written communications to their relatives and friends outside the community. There were no public or private schools or madrasas; families sent their children to study under the guidance of clerics who organized regular classes in a local mosque or the cleric's home during winter season, when people were not engaged in farm work. Modern educational institutions were not established in Shibar until the late 1940s. For the first time the state built a school (grades 1-3) for boys and later promoted it to an elementary school, the Shibar Elementary School, SES in 1959.'2 A school (grades 1-3) for girls was established in 1962, administered by the head-teacher (principal) of the SES; Ahmad Jan (1938-2010), son of Afghan, a progressive tribal chief employed to teach at the school. The Girls School did not have a dedicated building and the students would gather at a local mosque or a private home for regular classes. Although the conservative cultural milieu did not endorse women work in the public arena, after Ahmad Jan resigned from teaching his sister Sanam became a role model for women as she agreed with her father's decision to teach at the girls school.

Teachers in the Shibar School were Shias and Sunnis. At first Shia teachers gave preferential treatment to Shia students, this declined as the number of Ismaili teachers grew in the 1970s and more students from Shibar graduated from institutions of higher education and started teaching at schools there. Teachers coerced students to bring gifts, food, kindling for heating the room and cooking, etc. Students endured harsh punishment when they were late to class or did not master their studies. They eventually rebelled against the repressive academic administration and organized a protest demonstration in 1967, boycotting classes and demanding that the government punish autocratic teachers who abused their position. The government intervened, reconciled students and teachers and since then students were no longer obligated to bring gifts of any kind to their teachers. The numbers of students (male and female) increased in subsequent years as elementary and intermediate schools were built throughout Shibar. A number of students attended high schools, technical and vocational schools, military school and college in Kabul, as well as institutions of higher education outside the country. ${ }^{13}$

In institutions of higher education students developed a new socio-political awareness as they were exposed to peers who were members of political organizations espousing radical ideologies for social transformation. These contacts influenced many Ismailis to fight to reform rigid social, cultural and political structures. Ismaili intellectuals were divided into three groups: revolutionary, reformist and traditionalist. The revolutionaries advocated socio-political and economic transformation through grassroots participation, while reformists (pro-Soviets) supported sociopolitical and economic transformation based on a Soviet political system and viewed a military coup as a shortcut to revolution. Traditionalists favored the status quo and threw their support behind the Ismaili religious leader. Intellectuals of revolutionary backgrounds played a critical role in the dissemination of revolutionary politics, organizing people and students to oppose societal injustice and expose corrupt system of leadership. They were successful in mobilizing grass-roots support for social, political and cultural changes partly because they were educated and had a good grasp of local and national politics and some of them also belonged to locally prominent families such as the author and Khodayar Faiyaz.

12. Students of the Shibar School were ranked the highest in the province in terms of their school performance and they impressed King Zahir when he visited Shibar in 1960; students and the people greeted him and the king had a lengthy conversation with the students about their studies and praised them for their work. The King awarded a Mont Blanc pen to the author and monetary gifts to the students to further encourage them to focus on their studies.

13. The author was awarded a US government scholarship to attend high schools in the United States in 1969-1970. 


\section{The Soviet-backed Regime and Developments in Shibar}

After pro-Soviet forces seized power in a coup in April 1978, they resorted to the use of force 10) implement development policies that were based on the Soviet model of socialism. The regime arrested influential figures and others suspected of working against the regime including the Ismaili religious Ieader Nasir Naderi and his brothers. Mir and Arbab were stripped of their power as the regime no longer recognized this traditional governing institution. The regime's coercive reform policies carricd out from the top without grassroots support not only antagonized conservatives but also stirred intertribal conllict. Some people benefited from the reform supported the state while others who had opposed it suffered. The plight of the poor prior to and after the April coup and opposition to the regime's policies has been described in these words:

\footnotetext{
"The arbab always knew exactly how many had to pay tax and what they should paly. The poor did not have to pay. But the big got a share from their workers and sharecroppers, so that way everyone paid. Under Daoud |President, 1973-1978|, the tax got bigger. If you could not pay, the poliee were sent to collect you. We patd tax every August and September. Some of the arbabs extracted money for themselves. A good thing about Taraki [President. A pril 1978 - September 1979] was that he ended the arbab system. All his reforms were good; people were happy especially about the eanceling of unfair debts. However, I tannot support Taraki because it was his reforms which brought the troubles. Since then our houses have been destroyed, our lields plundered, our animals stolen and our children lost to us, ${ }^{-1 / 4}$
}

The regime appointed young and inexperienced party members to implement its policies and counter anti-systemic movements. Faramurz Teemar of Madarqol became the ruling party's regional secretary and played a key role in organizing support for the regime and helping to arrest those suspected of anti-government propaganda. The state intelligence agency arrested Safdar son of Salar, an lsmaili from Iraq and executed him. Mir Afghan of Iraq, a staff member of the Education Department in Bamiyan was arrested in 1979 on suspicion of anti-state activitics. After a few days of torture and interrogation he was freed as the regime plotted to monitor his movements and identify his mentor and associates.

In Kabul the regime raided the house of a tailor, Boland Khan known as Khalifa Bolandkhu, on suspicion of sheltering Manuchehr, cousin of the imprisoned Ismaili chief Naderi who organized Ismailis in Baghlan against the regime. They arrested Boland Khan and a number of others and executed them for not disclosing information about the shereabouts of Manuchehr, although they had no knowledge about him. The state intelligence agency arrested and executed individuals loyal to Naderi and his brothers that included Mir Ahmad Jan, a conservative tribal chief from Shibar, Abdul Hakim son of Gul Ahmad, a high school graduate, and petty businessmen Abdul Samad and his brother Abdul Aziz and Sayed Jalal son of Mubarak Shah. The regime also targeted radical Ismailis: Captain Noor Mohammad was arrested in Kabul and the intelligence agency tortured him in an attempt to make him disclose the identities of his associates. Failing to break Noor Mohammad's spirit, they released him and kept him under surveillance to track his movements and find information about his friends, hovever Noor Mohammad fled to the safety of Shibar.

\section{Radicalization of Politics in Shibar}

People regarded the regıme's policies of development as anti-Islamic and anti-traditions. Clerics and intellectuals of secular and religious backgrounds spearheaded social movements to topple the regime. Noor Mohammad and his cousin Khodayar Faiyaz, a school teacher organized an armed 
resistance group in Shibar to light the repressive system of governance. ${ }^{5}$ They along with their Sunni counterparts under the command of Matvlavi Faizullah Sabir, a cleric from Ghandak fought the government forces. Growing insurgency caused district governor Mohammad Ali, a Tajik from Kahmard and other state employees to leave Shibar. Kabul deployed reinforcement troops and regained control of the region. The pro-Soviet party member Teemar scized the opportunity and organized a rally in suppert of the regime, however the insurgents soon regained control of Shibar and Teemar fled. Sabir ordered his men to seize Teemar's property as war booty to be distributed among his men, but Neor Mohammad prevented them from doing so in order to avoid further tribal retaliation. In December 1979 Noor Mohammad, Faiyaz and Sabir launched a joint offensive on a government base in Shashpool, forcing officers and soldiers to surrender. Sabir's men executed a few of the captives, an act that strained relations with Noor Mohammad, who vehemently opposed murdering soldiers who defected or surrendered.

After the Soviet invasion in December 1979, the puppet regime formed a tribal militia unit to light the insurgents. The Ismaili chief Nasir Naderi and his brother Mansoor Naderi had pledged to support the regime and were released from prison while his other brothers had been executed. The two brothers had instructed followers in Shibar to support the regime that caused people to become divided into supporting and opposing the regime. A number of Ismailis headed by Qurban and his associates Faramurz and Shir Mohammad formed pro-government tribal militias. Tribal politics guided their actions as militia feaders used their position to eliminate individuals who disagreed with their policies and actions. The kidnapping of Mir Afghan from his home in Iraq in 1980 and his murder by pro-government militias who held personal grudges against him ignited elan conflict in the region. This incident infuriated Mir Afghan's father, Mir Ahmad to avenge the murder of his son. When Islamic militias had launched an offensive on Iraq killing five persons (two tvomen and three men) and ransacking their houses, Mir Ahmad returned to Iraq and people there accused him of collaboration with Islamic militias and responsibility for destruction in Iray (one of Mir Ahmad's opponents murdered him in Kabul in 1988). Ismailis suffered another loss after Islamic insurgents seized Yakatwlang. The government mobilized scores of Ismailis and dispatched them to fight the insurgents there but they svere defeated and after surrendering most were summarily executed, only a few lucky ones escaped in the dark hours of the night and returned home. This incident did not deter naïve Ismailis who were lured by the promise of financial reward from the government to fight the insurgency. During a battle for control of Bamiyan Islamic insurgents inflicted heavy casualties on pro-government militias; Qurban, Faramurz, Shir Mohammad and some 40 of their associates were killed.

Radical Ismailis in Kabul continued to oppose the regime despite heavy crack down by security forces. The state intelligence agency monitored their movements and arrested those who were engaged in anti-state activities. In 1980 security agents arrested Ferooz Nawrooz in Kabul and released him after a few months of imprisonment.

Ismailis lacked resources to sustain the struggle and their leaders opposed imposing taxes and extorting money from the people as commanders of the Islamic fundamentalists did. Noor Mohammad and Faiyaz left Shibar for Kabul and in May 1980 proceeded to Tehran, Iran to study international situation with regards to the war of national liberation in Afghanistan. The author cscaped an arrest attempt by security agency in late 1979 was forced to flee to Iran in July 1980, he met Noor Mohammad and Faiyaz in Tehran and a decision was made to explore the possibility of securing independent financial resources to sustain the armed resistance in Shibar.

15. Hafizullah Emadi, 2001. "Radicul Political Movemenis in Afghanistan and their Politics of Peoples' Empowermemi and Liberation." Central Asian Survey, 20:4, pp, 427-450. 
Noor Mohammad returned to Shibar in late December 1980 and several months later Faiyaz Ieft Iran for Karachi, Pakistan where he met the author lor further discussions on strategies of ivar of liberation in Shibar prior to returning home. The Ismaili chief Nasir Naderi left Afghanistan for England and his brother Mansoor Naderi took charge of the community and with the support of the government consolidated his power base in Kayan, Baghlan and tried to influence developments in Shibar. Islamic fundamentalists continued to harass the Ismailis and this factor caused people to appeal to Noor Mohammad and Faiyaz to re-organize a tribal armed group to defend the community's interest. A Leadership Council ivas formed to guide the day-to-day affairs of the community; Mohammad Ewaz Iqbalzada was selected as Chair, Noor Mohammad as army commander, Faiyaz as political advisor, and Ahmad Ali Qurban as a judge. This development in Shibar encouraged young men like Azizullah Mehrzad and other radicals to join the anti-state armed struggle there.

In 1983 Noor Mohammad and Faiyaz had a falling out over a varicty of issucs, and public pressure caused them to visit Kayan seeking mediation by the Ismaili chicf, who decided that Faiyas. must remain in Kayan while Noor Mohammad return to Shibar. The Ismaili chief sent a trusted man. Baz Mohammad Mazari known as Bazak, to Shibar to ensure the region remained under his control. In 1985 Bazak assassinated Noor Mohammad and then fled to Kayan and the leadership sent another trusted man to Shibar to promote and defend his interest. The situation in Shibar remained tense and a year later chair of the Leadership Council Iqbalzada was murdered and since then Shibar remained under Kayan's control. Local leaders were semi-literate, lacked vision and necessary skills in managing community affairs. They were apprehensive of social works undertaken by Ismaili intellectuals in Shibar and worked to throw up hurdles to distupt their activities. Delavar Azimy worked several years for Frecdom Medicine as a member of the medical staff in Shibar, delivering basic health care services; he was forced to leave the region and settled in Pakistan.

\section{Islamic Fundamentalists: Domination of Politics in Shibar}

Ismailis became weak as a result of internal conflict and this paved the way for Shia fundamentalists to seize control of the region. They forced Ismailis and Shias alike to follow their rule and provide men, money and material to the war fronts. Although Shia intellectuals of revolutionary backgrounds such as Rajab Iqbalzada, Suhrab Mubashir, Mehrab Faez, Mohammad Afial and others who were comrade-in-arms with their Ismaili counterparts diligently worked to protect Ismailis from any abuse by the Shia leadership and safeguard their vested interest, a number of Ismailis left Shibar. During the civil strife schools were closed down and most school structures were destroyed. The war caused many families to abandon their homes and properties. Most regarded Baghlan to be safe place for them to settle. This situation on the one hand and Kayan's encouragement of migration of Ismailis to Baghlan in an attempt to expand its base of support caused many families to leave Shibar. In 1992 about 700-800 families from Shibar and at least 200 families from Iraq settled in Baghlan where each family was given 10 Jeribs of rain-fed land in the deserts of Khaja Alwan and Kilagay in Pol-e-Khumri." Lack of employment opportunities in Baghlan caused a significant number of internally displaced people to join the $80^{\text {th }}$ Army Division under the command of the Ismaili warlord who promoted a few of these people to the ranks of captain, colonels and generals, intending to use them for consolidating his rule. Individuals who were suspected of having hidden agendas were subject to severe punishment. 


\section{The Taliban and Repression in Shibar}

The Taliban fought the Ismaili chicf, Mansoor Naderi, defeated him and forced him to leave Baghlan for neighboring Uebekistan. The Taliban militias conquered Bamiyan, forcing Hizb-eWahdat e-Islami-e-Afghamistan, Islamic Unity Party of Afghanistan under the command of Karim Khalili to abandon the region. Taliban fighters scized control of Shibar on September 13, 1998. They set lire to residenees; 298 houses were destroyed and 643 sustained severe damage. Shunbul and Kalu bore the brunt of the destruction as educational and health eenters and irrigation systems were destroyed. The Taliban's repressive measures caused greater outsward migration of Ismailis to Kabul. In 1999 there were 346 families from Shibar, 157 from Kalu, 174 from Iraq and 34 from Shunbul settled in Kabul. Numerous other families were forced to seek refuge in Pakistan. The Taliban encouraged Kochis to return in order to use them as a fifth column in the region that paved the road for about fifteen Kochi families to return in 1999. Tajik residents of Bamiyan and Ghandak and Hazaras loyal to Mohammad Akbari, head of the Hizb-e-Walidal Milli-e-Islami-e-Afghanistan, National Islamic Unity Party of Afghanistan who split from Khalili supported the Taliban. A resident of the Kalu valley described Taliban's brutality in these words:

"They |Taliban| came in tanks. trucks and four-wheel drives. They lired on everyone they saw. They stupped and sprayed our houses with petrol and then the soldiers that followed picked out the wood from the burned houses and carried the poles atvay. This happened in September 1999. They also took all our animals. Around two hundred men from this valley were captured and taken to prison. Later. some of the relatives were able to collect money and bribe the Taliban to release them but most did not get out of prison until after the fall of the Taliban. When it was reported that the Taliban were coming up the valley, most of us fled to the mountains. We hid there for a full week. There were few caves and it was difficult to live in the mountains, Food was scarce. We came back to lind our animals gone and the houses destroyed. The second time the Taliban came. many people left the area for good. That wals in March 2000)."18

When a group of Shias attacked the Taliban in Shibar the Taliban called for backup: as reinforcements arrived they randomly lired on innocent bystanders. In Iljanak Yawar Murad Ali, Rahindel Mehrdel, and Mohayuddin Ghulam Rasul were shot dead on the spot. The next day the Taliban randomly rounded up eighteen men working on their farms in Daki and transferred them to a detention center in Bamiyan. The Taliban executed nine of their captives simply for being Hazaras (Table 3), When Taliban militias called Habibullah Emadi, Educational Superintendent of Shibar to the execution chamber he asked them to let him say his prayers. However he said his prayers the same ivay Sunnis say the five daily prayers and convinced the Taliban that he was a Sunni Muslim. so they released him and the nine remaining captives. ${ }^{19}$ Army officer Mohammad Naim Nazar and his companions Pirdad son of Ghulam Reza fled Kayan after the Taliban seized the region and on their way home to Shunbul Taliban militias shot them to death.

\section{The Post-Taliban Period: Dawn of a Modern Era in Shibar}

Ismaili intellectuals who escaped execution by the Soviet-backed government, the civil war and those who migrated to the West continued their isolated struggle for social, cultural and political transformation in their community. The Ismaili Imam, the Aga Khan was aware of developments in

17. FOCUS Humanitarian Assistance, Unpublished report, Islamabad. Pakistatn. 1999.

18. Liz Alden Wily, op. cil., pp. 29-30.

19. Discussions with Habibultah Emudi (1954-2006). Edueational Superintendent for the Shibar district. Bamiyan. May. 2005. 
Table 3

Ismailis Executed by the Taliban in a Bamiyan Detention Center, 1998

\begin{tabular}{|l|l|l|}
\hline \multicolumn{1}{|c|}{ Name } & \multicolumn{1}{|c|}{ Father Name } & \multicolumn{1}{c|}{ Village } \\
\hline Abdul Hamid & Ali Ahmad Jan & Quchangi \\
Ali Madad & Ali Pana & Quchangi \\
Amir Jan & Ibrahim & Rashak \\
Bakhtiyari* & Sayed Mohammad & Kuhna-Qulah \\
Ghulam Sakhi & Paiwand & Qala-c-Abbas \\
Jamaluddin & Salih & Kuhna-Qalah \\
Jan Bakhsh (cicric) & Hasan & Kuhna-Qalah \\
Khudadad & Khangul & Kuhna-Qalah \\
Rabi & Khudadad & Kuhna-Qalah \\
\hline
\end{tabular}

Nole: * Menber of the Shia eommunity.

Source: Discussions svith Ismailis of Shibar, $20(17$.

the Ismaili community and since the 1960s his efforts to establish modern institutions and provide aid for modernization of the country and the Ismaili community were stymied by prevailing hostile political situation in Afghanistan; however he was determined to abolish the hereditary system of leadership in which a Pir/Mukhi is succeeded by his son and ruled supreme. To this end in 1996, the Aga Khan instructed his institutions to provide emergency humanitarian aid to Afghanistan and a delegation that included the author visited Badakhshan to study the situation and devise appropriate strategies for assistance to residents of the province, including Ismailis; the delegation also visited Baghlan for the same reason. Soon afterward FOCUS Humanitarian Assistance, an affiliate of the Aga Khan Development Network, AKDN established branch offices in Kabul, Baghlan and Badakhshan to provide emergency aid to the poor and the IDPs.

The Aga Khan also decided to establish modern institutions to guide the Ismaili community. He believed that a modern era necessitates modern institutions and a new generation of leaders who are educated in the spirit of modern times were needed to lead the community. Ismaili chief Nasir Naderi and his brother Mansoor Naderi were removed from leadership posts in July 2002 after the Aga Khan established the National Council for Afghanistan, NCA and other institutions and appointed institutional leaders and Mukhi and Kumadia (assistant to Mukhi) at each Jamatkhana (house of gathering) in several Ismaili-settled regions. The leaders are appointed for a three-year term which is renewable once for a second term. This development heralds the beginning of a new era for the Ismailis - after hundreds of years of servitude they are increasingly becoming religious leaders and institutional leaders and assuming positions that once were held exclusively by men of Sayyed descent.

In Iraq people loyal to the former leadership resisted appointment of new leaders, forced Mohammad Ishaq to renounce his appointment as Mukhi and physically assaulted Juma Khan Wafakish, vice president of the NCA when he visited Iraq. Ismaili intellectuals continued the struggle for modernization and worked to rally people in support of the Imamat initiatives. The establishment of modern institutions was welcomed by many Ismailis who settled in the West. The author met prominent social activists and persuaded them to engage Ismaili expatriates to express solidarity with the appointed leaders and play a role in post-ivar reconstruction efforts. To this end they collected funds for rebuilding the Shibar High School for boys and the intermediate schools for girls in Shibar and forwarded it to the AKDN in charge of development projects in the 
region. Individuals spearheading the drive included Khodayar Faiyaz, Delawar Azimy in Canada, Shahabuddin Shibari and Saheb Datad Aiam in Germany. Table 4 lists the number of students and teachers in schools in Shibar.

Table 4

Number of Schools, Students and Teachers in Shibar, 2005

\begin{tabular}{|l|l|c|c|c|c|}
\hline \multicolumn{1}{|c|}{ Region } & \multicolumn{1}{|c|}{ Type of School } & $\begin{array}{c}\text { No. of } \\
\text { Students }\end{array}$ & $\begin{array}{c}\text { No. of } \\
\text { Teachers }\end{array}$ & $\begin{array}{c}\text { Professional } \\
\text { Teachers }\end{array}$ & $\begin{array}{c}\text { Year } \\
\text { Established }\end{array}$ \\
\hline Birgilich & Elementary (Boys +Girls) & 390 & 4 & None & $1383 / 2004$ \\
\hline Bululah & Elementary (Boys+Girls) & 342 & 7 & None & 1973 \\
& Elementary (Girls) & 170 & 2 & None & $1383 / 2004$ \\
\hline Iraq & Intermediate (Boys) & 186 & 8 & 3 & $1356 / 1977$ \\
& Elementary (Girls) & 247 & 6 & None & $1381 / 2002$ \\
\hline Julat & Elementary (Boys+Girls) & 255 & 6 & None & $1381 / 2002$ \\
\hline Kalu & Intermediate (Boys) & 302 & 11 & None & $1357 / 1978$ \\
Sadbarg & Elementary (Boys+Girls) & 200 & 5 & None & $1383 / 2004$ \\
Ghurghura & Elementary (Boys+Girls) & 290 & 6 & None & $1381 / 2002$ \\
Sadbarg-2 & Elementary (Boys+Girls) & 192 & 7 & None & $1383 / 2004$ \\
Paimori & Elementary (Boys+Girls) & 125 & 7 & Nonc & NA \\
\hline Shibar & Elementary (Boys+Girls) & 180 & 7 & None & $1357 / 1978$ \\
& Intermediate (Boys) & 340 & 10 & 2 & $1349 / 1970$ \\
& Elementary (Girls) & 160 & 7 & None & $1357 / 1978$ \\
\hline Shunbul & Elementary (Boys+Girls) & 473 & 10 & 3 & $1382 / 2003$ \\
\hline Total & & 4342 & 102 & 8 & \\
\hline
\end{tabular}

Nese: Exclusively Shia-setted villages while the rest are mixiure of Shias and Ismailis.

Source: Discussions with late Habibullalı Emadi, Districi Educational Superintendent. Slubar, 20015.

AKDN helps communities irrespective of their ethnic backgrounds and belief systems and since 2002 it has sponsored numerous community development projects in Shibar that benefited Sunnis, Shias and Ismailis. Its projects in Shibar included construction of a power plant in Kalu and shelters in Shashpool for families whose houses were destroyed by the Taliban. There was no health center in Shibar and families in remote areas had to visit a medical center in Bamiyan which typically took a full day of travelling. The International Medical Corps (IMC) built a small mobile clinic in Shunbul and when it left the area AKDN took over and upgraded it to a Basic Health Center, BHC. AKDN also built BHCs in Iraq, Kalu, and Ghandak and modernized the Bamiyan Hospital. In addition to these projects AKDN works in Shibar, Panjab, Waras and Bamiyan city as implementer of the National Solidarity Program, NSP projects that include micro-hydropower, water supply. irrigation, roads, etc, (Table 5), Although the AKDN employed a great number of Shias at its various development programs, Shia political and religious leaders within and outside the state did not appoint any Ismaili to senior or junior posts in the government nor involve them in the Shia-led institutions and enterprises. 
Table 5

Development Projects Funded or Implemented by the AKDN in Bamiyan

\begin{tabular}{|l|l|l|l|}
\hline \multicolumn{1}{|c|}{ Region } & \multicolumn{1}{|c|}{ Type of Project } & Funding Agency & Vear \\
\hline Bamiyan Center & $\begin{array}{l}\text { Hospital/Construction of wards } \\
\text { GSM Mobile Phone System }\end{array}$ & $\begin{array}{l}\text { AKDN } \\
\text { AKDN/ROSHAN }\end{array}$ & 2003 \\
\hline Ghandak & BHC & AKDN & 2003 \\
\hline Iraq & BHC & AKDN & 2003 \\
\hline Kalu & BHC & AKDN & 2003 \\
\hline Panjab & Boys School (Rehabilitation) & AKDN & 2003 \\
& Girls School (Rehabilitation) & AKDN & 2003 \\
\hline Shibar & Boys School & AKDN & 2002 \\
Qalat-c-Naw & Girls School & AKDN & 2003 \\
Amanqol & Water Supply Project & USAID & 2002 \\
Birgilich & Repairing and Expanding Roads & Denmark & 2004 \\
Sar-e-Khushak & Water Supply/Irrigation & Denmark & 2004 \\
\hline Waras: Shinya & School & AKDN & 2004 \\
\hline Shunbul & Water Supply Scheme & USAID & 2002 \\
\hline Waras and Panjab & I00 shallow wells & ECHO & 2003 \\
& 100 shallow wells & ECHO & 2004 \\
\hline
\end{tabular}

Note: - European Commission Humanitarian Aid Office.

Source: AKDN, 2065.

Table 6

Candidates for Shura-e-Milli, Parliament, September 18, 2005

\begin{tabular}{|l|c|c|l|r|c|}
\hline Province & $\begin{array}{c}\text { No. of } \\
\text { Seats }\end{array}$ & $\begin{array}{c}\text { No. Registered } \\
\text { Voters }\end{array}$ & \multicolumn{1}{|c|}{ Candidate } & $\begin{array}{r}\text { No. of } \\
\text { Votes }\end{array}$ & Percentage \\
\hline Bamiyan & 4 & 178,979 & $\begin{array}{l}\text { Mir Jihaduddin Mirzada } \\
\text { Mohammad Husain } \\
\text { Mominzada }\end{array}$ & $\begin{array}{r}1,042 \\
684\end{array}$ & 0.9 \\
\hline Kabul & 33 & $1,206,540$ & Noor Ali Shayan & 77 & 0.6 \\
\hline
\end{tabular}

Source: <http//sviviv.JEMB org >, site accessed on November 7. 2005. 
A major development in post-ivar Shibar is peoples' participation in the parliamentary election held on September 18, 2005. Sectarian consideration was a major aspect of voting as the Shias, Sunnis and Ismailis tended to cast their vote for candidates of their own communitics. The NCA backed their own candidates although they lacked adequate qualifications to contest the parliamentary election. Mohammad Husain Mominzada, a native of Kalu residing in Kabul, was nominated a candidate from Shibar and Noor Ali Shayan from Kalu to contest the election from Kabul. Mir Jihaduddin Mirzada son of late Mir Ahmad Jan, a tribal chicf in Shibar was supported by the former leadership as a candidate from Shibar. These candidates lost the eleetion (Table 6). Ismailis were a minority in Shibar and the Shia Hazaras and Sunni Tajiks supported their own respective candidates.

\section{Conclusion}

Ismailis endured years of neglect. marginalization and injustice. They lacked the means to transform the status yuo and organizations to chart the path for reform. Access to modern education, exposure to political ideas in the 1960s and communication with the outside world and the desire to end their perceived socio-political marginalization helped the radical movement to take root in Shibar. Enlightened men and radicals advocating societal justice intensified their struggle for reform despite daunting risks and obstacles. Their efforts and dedication to their cause contributed to a greater social and political atvareness among the people that paved the way for reform in the socio-political arena. The struggle for reform was rejuvenated after the Aga Khan abolished the hereditary system of leadership, established modern institutions and appointed new leaders to guide the community. Economic development in Shibar improved people's lives. AKDN support provides many villages in Shibar with aceess to solar power, schools, health facilities, markets and information beyond their immediate community boundaries. New roads are being built that connect villages to the main road, ending centuries of geographical isolation for the region. Developing areas benefit when peoples' desire to better their lives and improve their communities as a whole is matched by supportive guidance and aceessible leadership. Bamiyan's Ismaili community, previously hindered by physical barriers as well as political and ideological hurdles created by local authority figures motivated by self-interest or self preservation, now has an opportunity to move beyond traditional constraints and integrate with the modern world. 